\title{
Community structure and spatiotemporal patterns of macrozoobenthos in Lake Chaohu (China)
}

\author{
Yongjiu Cai ${ }^{1}$, Zhijun Gong ${ }^{1, *}$, Ping Xie ${ }^{2}$ \\ ${ }^{1}$ State Key Laboratory of Lake Science and Environment, Nanjing Institute of Geography and Limnology, \\ Chinese Academy of Sciences, 73 East Beijing Road, Nanjing 210008, PR China \\ ${ }^{2}$ Donghu Experimental Station of Lake Ecosystems, State Key Laboratory of Freshwater Ecology and Biotechnology, Institute \\ of Hydrobiology, Chinese Academy of Sciences, Wuhan 430072, PR China
}

\begin{abstract}
Lake Chaohu, the fifth largest freshwater lake in China, has been subjected to severe eutrophication and cyanobacterial blooms over the past few decades. However, little is known about the macrozoobenthic assemblages in this lake. To characterize the community structure and spatiotemporal patterns of macrozoobenthos in Lake Chaohu and to elucidate the environmental factors that regulate the benthic community, a bimonthly investigation was conducted at 9 stations from September 2002 to July 2003. Principal component analysis suggested that there was a decrease in trophic status from west to east in this lake. A total of 19 taxa were recorded, and the most abundant organisms were members of Oligochaeta and Chironomidae. Two-way ANOSIM indicated significant differences in community structure among stations $(\mathrm{R}=0.417, \mathrm{p}<0.001)$ but not among months $(\mathrm{R}=0.058, \mathrm{p}=0.128)$. Mantel tests showed that spatial changes in macrozoobenthic assemblages were similar across most sampling occasions. A BIO-ENV analysis showed that the concentrations of total nitrogen, total phosphorus, ammonium and dissolved oxygen in the benthic layer were strongly correlated to the community structure of macrozoobenthos in Lake Chaohu. Compared with a study conducted in 1980 to 1981, benthic assemblages shifted from dominance by Corbicula fluminea and gastropods to dominance by oligochaetes and chironomids in the present study. Our results have implications for benthic biodiversity conservation in shallow lakes along the Yangtze River undergoing eutrophication.
\end{abstract}

KEY WORDS: Lake Chaohu $\cdot$ Shallow freshwater lakes $\cdot$ Eutrophication $\cdot$ Cyanobacterial blooms Spatial pattern

Resale or republication not permitted without written consent of the publisher

\section{INTRODUCTION}

There is a clear relationship between the eutrophication of fresh water, and human sources of nutrients such as fish culture, urban and agricultural runoff, industrial wastes and domestic sewage effluents (Heisler et al. 2008). Under certain conditions, an excess of nutrients can fuel excessive growth of phytoplankton, which can reduce light penetration, limit macrophyte growth, and create oxygen depletion through algal decomposition (Smith et al. 2006). Such conditions threaten the abundance and diversity of commercially and scientifically important bio- logical resources. Moreover, increased nutrient loading may confer competitive advantages to harmful algal blooms (HABs) over other algal species (Anderson et al. 2002). HABs exert great pressure on freshwater ecosystems, either due to production of toxins or to the manner in which high biomass alters food web dynamics.

In the middle and lower Yangtze River drainage basin, there are 108 freshwater lakes with a surface area $>10 \mathrm{~km}^{2}$ that account for $51.3 \%$ of the total freshwater lake area in China (Wang \& Dou 1998). These lakes are all shallow lakes and are subject to disturbances by natural and human activities (Liu 
et al. 2010). In the past decades, human activities have caused serious ecological and environmental damage (e.g. loss of biodiversity, over-exploitation, water pollution and eutrophication) in this region. Eutrophication has become one of the most prominent problems confronting these lakes. Several studies have revealed specific biotic and abiotic changes attributed to eutrophication in these lake ecosystems (Fang et al. 2006, Yang et al. 2008). However, current understanding of the effects of high levels of eutrophication on macrozoobenthic assemblages in lakes in this region remains poor. Large shallow lakes often possess significant environmental gradients (e.g. trophic status) and different habitats (Scheffer 1998), which provide good opportunities for revealing the effects of eutrophication on benthic community structure.

We studied the macrozoobenthic assemblages in a large shallow lake in this region. Lake Chaohu, the fifth largest freshwater lake in China, is located in the middle of Anhui Province and downstream of the Yangtze River. The lake is important for agriculture, aquaculture, tourism and recreation, flood control and shipping and is also a drinking water source for Chaohu city. In the past decades, the lake has undergone a serious detorioration in water quality with increasing development and urbanization, and coverage and duration cyanobacterial blooms have increased (Xie 2009). However, the macrozoobenthic community structure and its possible regulating factors have been poorly studied. The main objectives of the present study were to characterize the community structure and spatiotemporal patterns of macrozoobenthos in Lake Chaohu to identify environmental factors associated with significant differences in the composition and patterns of macrozoobenthos. Additionally, we examined possible long-term changes in macrozoobenthic assemblages in this lake by comparing our results with those of a study from 1980 to 1981 (Hu \& Yao 1981).

\section{MATERIALS AND METHODS}

\section{Study area}

Lake Chaohu $\left(31^{\circ} 25^{\prime}\right.$ to $31^{\circ} 43^{\prime} \mathrm{N}$, $117^{\circ} 70^{\prime}$ to $117^{\circ} 52^{\prime} \mathrm{E}$ ) has a surface area of $770 \mathrm{~km}^{2}$ and a mean depth of $3.0 \mathrm{~m}$. Freshwater input is dominated by the south-eastern watersheds, which discharge via the Yuxi River, whereas nutrient inputs are mainly from the north-eastern rivers (Fig. 1). The principal pollutant inflow to the lake is from Nanfei River, which discharges a total $1.8 \times 10^{8} \mathrm{~m}^{3}$ per year of untreated domestic and industrial wastewater from Hefei City into the west region of the lake (Xu et al. 2005). The discharge from city wastewater contains $18368 t$ of total nitrogen (TN) and $1050 \mathrm{t}$ of total phosphorus (TP) every year (Xie et al. 2005). The hydrology of the late and nutrient inputs result in a trophic gradient from west to east. Eutrophication of the lake water has increased steadily over the past decades; the trophic state index (TSI) has increased gradually from 1984 to 2004 (Shang \& Shang 2007). The excess of nutrients fuels excessive growth of phytoplankton and causes cyanobacterial blooms (Xie 2009). Cyanobacterial blooms (Microcystis spp. and Anabaena spp.) first appeared at the beginning of the 1950s, with no distribution in Lake Chaohu in the pelagic and southern zones until the 1960s (Deng et al. 2007). Since the 1980s, cyanobacterial blooms have occurred from May to November each year and have extended their coverage. In August 2003, a whole-lake cyanobacterial bloom was observed which reached a maximum thickness of $1.0 \mathrm{~m}$ (Xie 2009).

\section{Macrozoobenthos sampling and water chemistry}

Benthic samples were collected bimonthly at 9 stations from September 2002 to July 2003 (Fig. 1). Sta-

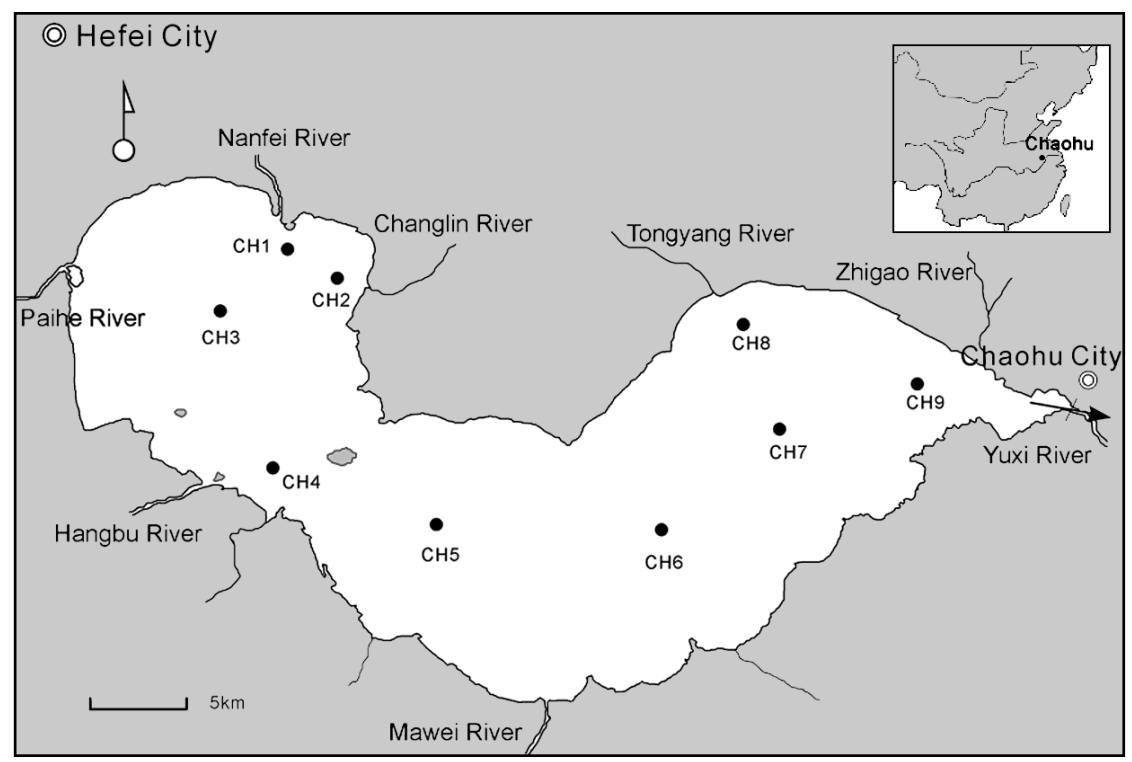

Fig. 1. Locations of the macrozoobenthos sampling stations in Lake Chaohu, China 
tions $\mathrm{CH} 1, \mathrm{CH} 2$ and $\mathrm{CH} 8$ were located near 3 main input rivers, the other stations were relatively equally distributed in the open water from west to east. Samples were collected with a $0.025 \mathrm{~m}^{2}$ modified Peterson grab; 3 replicate samples were taken at each site on each sampling date and were pre-sieved in situ at a smaller size fraction $(250 \mu \mathrm{m})$ to collect more of the fauna than is typical of many studies that use sieve sizes $\geq 500 \mu \mathrm{m}$. In the laboratory, the samples were sorted on a white tray, and the animals were preserved in $7 \%$ buffered formalin solution. Specimens were identified to the lowest level possible, blotted dry and weighed with an electronic balance (Sartorius BS-124, precision: $0.1 \mathrm{mg}$ ). Mollusca were weighed with their shells. The identification and classification of macrozoobenthos were mainly based on Liu et al. (1979), Morse et al. (1994) and Wang (2002).

Water depth and Secchi depth were measured in the field on all sampling dates. Water temperature, $\mathrm{pH}$, conductivity and dissolved oxygen (DO) were measured in near-bottom water $(\sim 0.5 \mathrm{~m}$ above the bottom sediments) using portable meters (Horiba D50). Integrated water samples were collected from the surface, mid-depth and bottom at each station and analyzed for water chemistry. The TN, total dissolved nitrogen (TDN), ammonium $\left(\mathrm{NH}_{4}{ }^{+}-\mathrm{N}\right)$, nitrate $\left(\mathrm{NO}_{3}{ }^{-}-\mathrm{N}\right), \mathrm{TP}$, total dissolved phosphorus (TDP), orthophosphate $\left(\mathrm{PO}_{4}{ }^{3-}-\mathrm{P}\right)$ and chlorophyll a ( $\mathrm{chl} a$ ) levels were measured in the laboratory according to standard methods (Jin \& Tu 1990).

\section{Data analysis}

A principal component analysis (PCA), based on a correlation matrix among samples, was used to analyze the physicochemical data. Data were logarithmically transformed (except $\mathrm{pH}$ ) to approximate normality.

Prior to analysis, the abundance data were converted to individuals $\mathrm{m}^{-2}$. Simple descriptors of community structure were calculated, including Margalef, Simpson and Shannon-Wiener indices. Multivariate statistical analyses, to examine variation in community composition at the temporal and spatial scales, were performed using PAST (Paleontological Statistics v2.14) (Hammer et al. 2001) and PRIMER (Clarke \& Warwick 2001). Macrozoobenthic community structure was compared among stations and months using analysis of similarities (ANOSIM) and non-metric multidimensional scaling (NMDS) based on a Bray-Curtis similarity matrix obtained from abundance data (Clarke 1993). ANOSIM is a nonparametric test of significant difference between 2 or more groups, and the difference between the withingroup and between-group rank similarities is expressed as the global $\mathrm{R}$ value, with a score of 1 indicating complete separation and 0 indicating no separation (Clarke 1993). Similarity percentage (SIMPER) procedures were also applied to determine the characteristic species that were primarily responsible for the ordination pattern if the global test statistic $R$ was significant at $\mathrm{p}<0.05$ (Clarke 1993).

We used the BIO-ENV procedure to identify any water quality (abiotic) variables that may influence macrozoobenthic assemblages (Clarke 1993). This procedure was used to identify the most potentially influential water-quality variables. Abiotic variables were added in a stepwise fashion to nonparametric Spearman correlations between the mean macrozoobenthos abundance (biotic) Bray-Curtis similarity matrices and the abiotic Euclidean distance similarity matrices (Clarke \& Warwick 2001).

Comparative studies of macrozoobenthos community structure over extended time intervals can provide insight into the responses of aquatic biota to long-term eutrophication and cyanobacterial blooms (Jackson \& Füreder 2006). In 1980 and 1981, benthic samples were collected at 22 sites in Lake Chaohu (autumn 1980, spring and autumn 1981) with a $0.0625 \mathrm{~m}^{2}$ modified Peterson grab and washed through a $250 \mu \mathrm{m}$ mesh size sieve; 9 of these sites were identical to our sampling sites (Hu \& Yao 1981). Thus, macrozoobenthos data from these 9 sites were used in a comparative analysis. Due to the lack of environmental data from 1980 to 1981 for Lake Chaohu, we used data from August 1987, which were obtained through a survey of 9 stations adjacent to those in our study (Tu et al. 1990). NMDS, ANOSIM and SIMPER analyses were used to examine benthic assemblages over the long term. Prior to all multivariate analyses, biological abundance data were square-root transformed.

\section{RESULTS}

\section{Environmental characterization}

Table 1 summarizes the physical and chemical measurements taken at the 9 study sites. In general, measurements related to trophic status varied greatly among sites. For example, TN concentration ranged from1.95 $\mathrm{mg} \mathrm{l}^{-1}$ at $\mathrm{CH} 8$ to $5.81 \mathrm{mg} \mathrm{l}^{-1}$ at $\mathrm{CH} 1$, and TP concentration also increased from $0.055 \mathrm{mg} \mathrm{l}^{-1}$ 
(CH8) to $0.196 \mathrm{mg} \mathrm{l}^{-1}$ (CH1). Concentrations of TN, TP and chl $a$ and the studied nutrients in the lake water column showed a consistent spatial pattern decreasing from west to east, indicating the gradient of trophic status in Lake Chaohu. Spearman correlation analyses showed that many variables were correlated with each other (see supplement at www.int-res.com/articles/suppl/m017p035_supp.pdf). When PCA was performed, the first 2 components accounted for 69.38 and $12.18 \%$ of the total variance of environmental variables, respectively (Fig. 2). The PC1 had a strong positive relationship with TN, TP, chl $a$ and nutrients and a negative relationship with DO, Secchi depth and water depth. The PC2 was most strongly related to $\mathrm{pH}$ and conductivity (positive relationships). Overall, the PCA suggested that there was a trophic gradient from west to east in Lake Chaohu.

\section{Community composition, spatiotemporal patterns and diversity}

In total, 19 macrozoobenthic taxa were identified between 2002 and 2003, including 5 Oligochaeta, 7 Chironomidae, 3 Bivalvia, 1 Gastropoda and 3 other miscellaneous species (Table 2). The oligochaete Aulodrilus sp. (26.7\% of the total macrozoobenthos abundance) and chironomid Glyptotendipes lobiferus (Say,

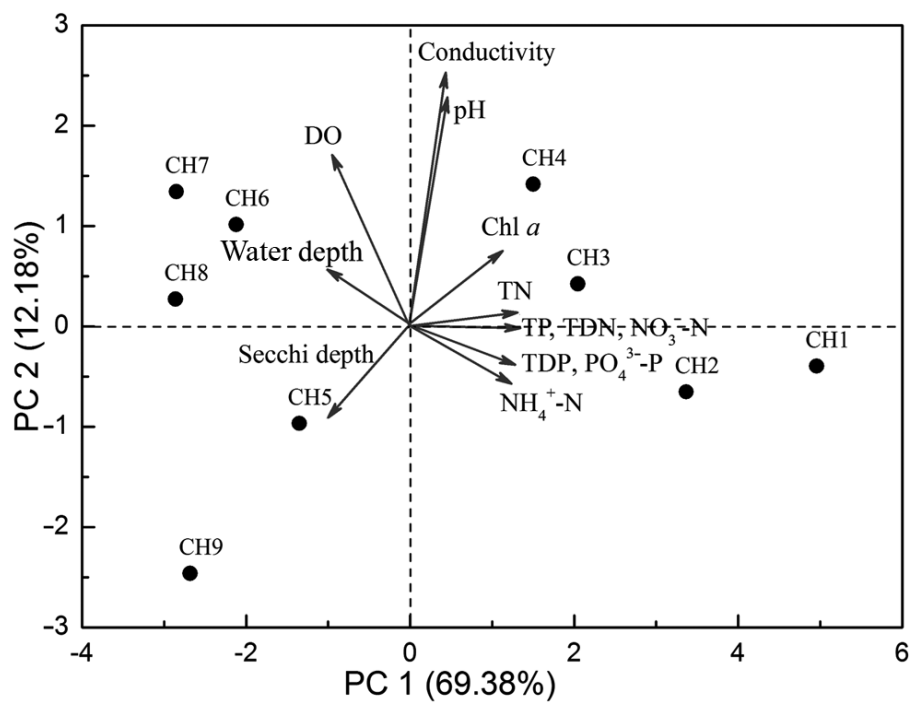

Fig. 2. PCA plots of the first 2 principal components of 13 environmental factors (except water temperature). Values on the axes indicate the percentages of total variation accounted for by each axis. See Table 1 for abbreviations

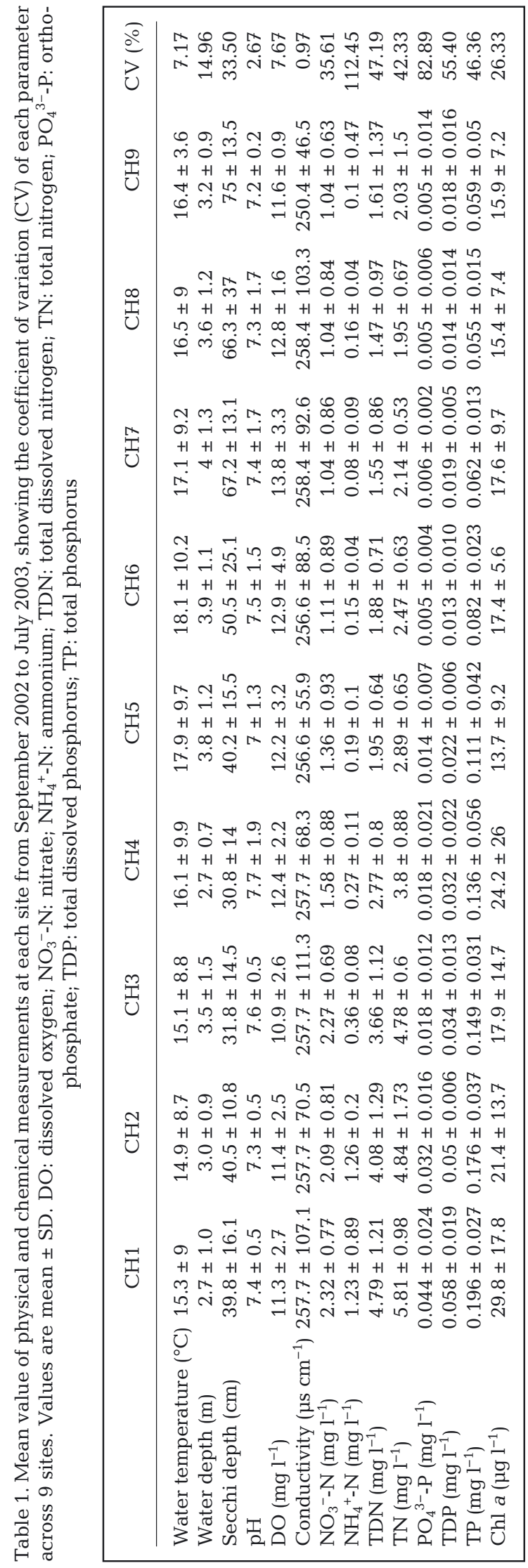


1823) $(30.3 \%)$ were the most abundant taxa in Lake Chaohu. The species Limnodrilus hoffmeisteri Claperède, 1862, Branchiura sowerbyi Beddard, 1892, Clinotanyus sp., Tanypus chinensis Wang, 1774, Corbicula fluminea (Müller, 1775) and Bellamya aeruginosa (Reeve, 1863) also commonly occurred in Lake Chaohu (each occurring in $>23$ of the samples) and accounted for $1.37 \%$ to $13.21 \%$ of the total abundance. Seven species showed extremely low occurrence $(<5$ samples) in our study. Generally, macrozoobenthic assemblages were exclusively dominated by Oligochaeta and Chironomidae, which together accounted for 77.8 to $99.9 \%$ of the total abundance in the 9 sampling stations (Fig. 3).

The most dominant taxa, Oligochaeta and Chironomidae, presented the highest abundance in 2 river mouth stations (CH1 and $\mathrm{CH} 2)$, which were several times higher than that in other stations (Table 2). In general, a trend of decreasing abundance was observed from west to east for these 2 dominant taxa. In contrast, bivalves (mainly Corbicula fluminea) and Bellamya aeruginosa showed relatively low abundance in all stations, with almost no individuals collected in $\mathrm{CH} 1$ and $\mathrm{CH} 2$ (Table 2). The 3 diversity indices indicated low biodiversity of benthic fauna in Lake Chaohu (Table 3), with relatively high values in 2 open water stations ( $\mathrm{CH} 4$ and $\mathrm{CH} 5)$.

\section{Multivariate analyses}

The 'interaction' of station and time, understood as the differing spatial pattern on the 6 sampling occasions, can be usefully depicted and tested in a fully nonparametric way using the method of Clarke et al. (2006). NDMS ordinations of the 9 stations were performed with arrows connecting adjacent station numbers for each sampling time. The test for seriation indicated that samples in nearby stations were more similar than distant ones at all sampling dates, with the exception of May 2003 (Fig. 4).

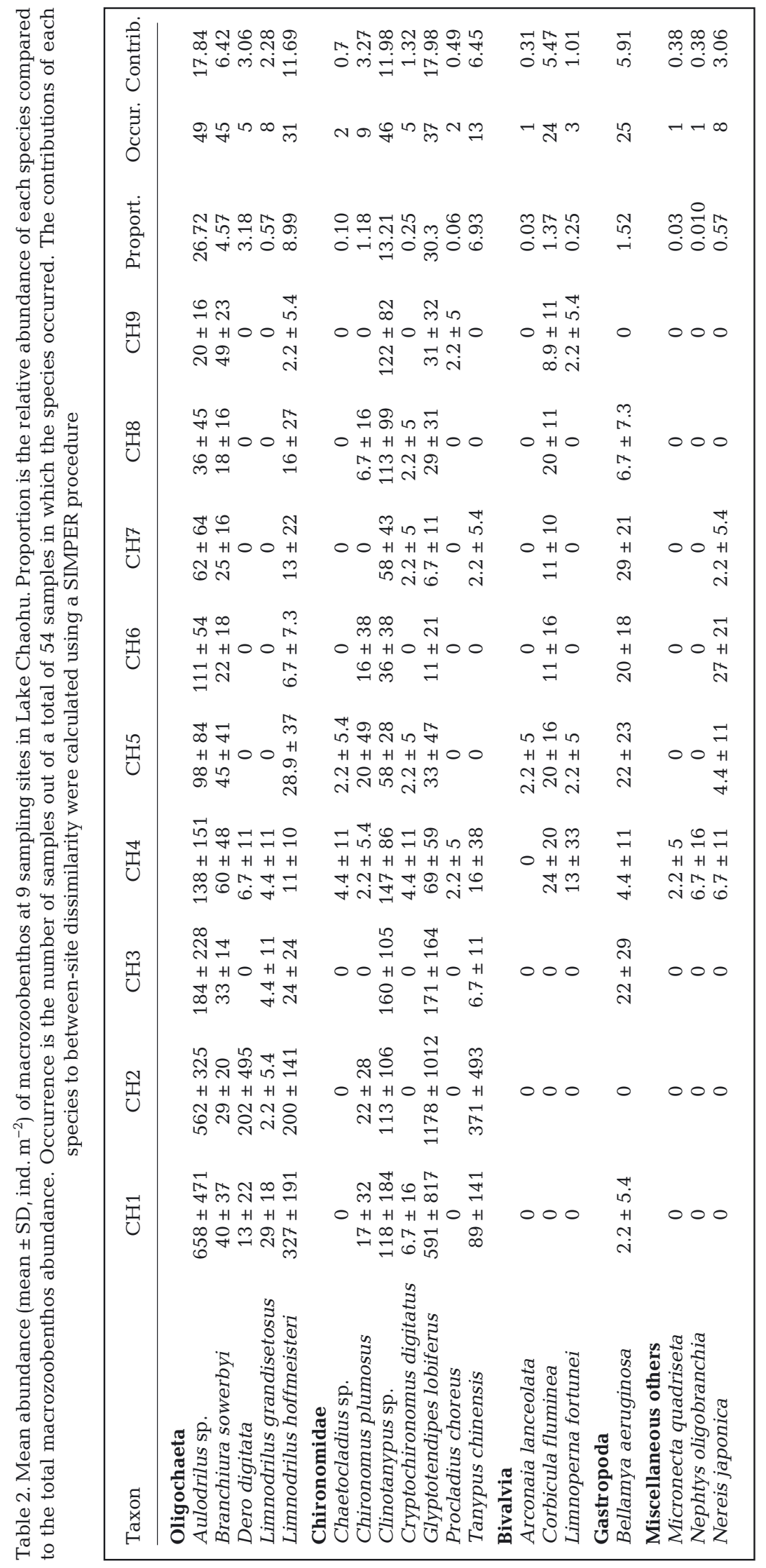




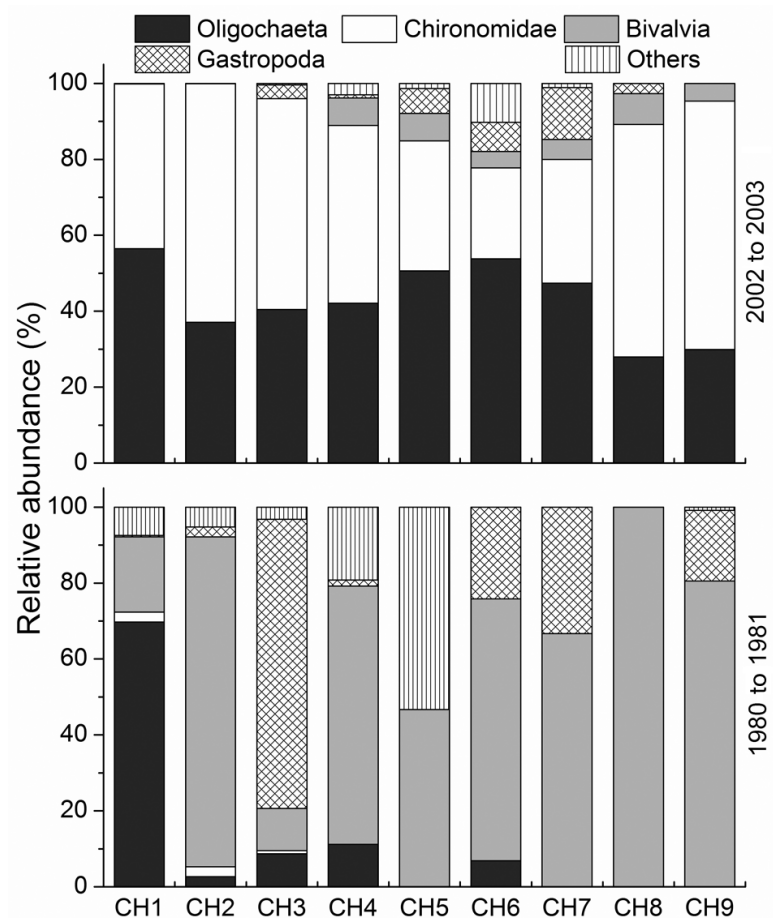

Fig. 3. Decadal changes in taxonomic composition of macrozoobenthos between 1980-1981 and 2002-2003 in Lake Choahu

Mantel tests showed that spatial changes in macrozoobenthic assemblages in September 2002, November 2002, January 2003, March 2003 and July 2003 were consistent with each other and were dissimilar from May 2003 (Table 4).

Two-way ANOSIM indicated significant differences in community structure among stations $(\mathrm{R}=0.417$, $\mathrm{p}<0.001$ ), while the structure was not significantly different among months $(\mathrm{R}=0.058, \mathrm{p}=0.128)$. The SIMPER procedure indicated that the species of Oligochaeta and Chironomidae contributed the highest proportion to the dissimilarity of benthic community across all sampling sites, which resulted from their great variation in abundance (Table 2).

Non-parametric regression of the ranked biotic and abiotic similarity matrices identified a combination of 4 physicochemical variables that provided the best

Table 3. Three diversity indices of macrozoobenthos at the 9 sampling stations in Lake Chaohu, which were calculated from the average abundance data over the 6 sampling dates

\begin{tabular}{|lccccccccc|}
\hline Index & CH1 & CH2 & CH3 & CH4 & CH5 & CH6 & CH7 & CH8 & CH9 \\
\hline Margalef & 1.33 & 1.14 & 1.25 & 2.72 & 2.06 & 1.44 & 1.68 & 1.45 & 1.28 \\
Simpson & 3.91 & 3.72 & 4.07 & 5.43 & 6.29 & 4.29 & 4.95 & 3.80 & 3.01 \\
Shannon-Wiener & 1.60 & 1.59 & 1.58 & 2.05 & 2.07 & 1.81 & 1.82 & 1.69 & 1.40 \\
\hline
\end{tabular}

match between the biotic and abiotic data sets $(\mathrm{TN}$, $\mathrm{NH}_{4}{ }^{+}-\mathrm{N}, \mathrm{TP}$ and DO, $\rho=0.430$ ). Fig. 5 shows the 4 most important environmental variables superimposed upon the biotic MDS ordination. $\mathrm{TN}, \mathrm{NH}_{4}{ }^{+}-\mathrm{N}$ and TP both increased from left to right in these plots and were strongly correlated with the first NMDS axis. DO appeared to increase from bottom right to top left and showed a strong negative relationship with both axes.

\section{Decadal changes in macrozoobenthic assemblages}

Our results showed significant increases in TN and chl a between 1987 and 2002-2003, whereas changes in TP were insignificant. Abundance of cyanobacteria increased $\sim 100$-fold after 2 decades (Table 4). In terms of macrozoobenthic assemblages, 6 gastropods: Bellamya aeruginosa, Alocinma longicornis (Benson, 1842), Parafossarulus striatulus (Benson, 1842), Semisulcospira cancellata (Benson, 1833), Stenothyra glabra (Adams, 1850) and Radix swinhoei (Adams, 1861); and 3 bivalves: Corbicula fluminea, Novaculina chinensis Liu \& Zhang, 1979, and Limnoperna fortunei (Dunker, 1857) were collected in 1980 and 1981. Benthic communities were mainly dominated by bivalves, gastropods and Gammarus sp., while oligochaetes and chironomids only accounted for 16.06 and $5.17 \%$ of the total abundance, respectively (Fig. 3). The most dominant species, C. fluminea, contributed to $40.48 \%$ of the total abundance. Non-parametric tests indicated that the abundance of oligochaetes and chironomids increased several dozen times, while bivalves decreased dramatically between the two sets of samples (Table 5).

The test for seriation indicated that macrozoobenthic assemblages from 1980 to 1981 showed no gradual changes from west to east (Fig. 6). NMDS showed that the benthic community at site $\mathrm{CH} 1$ in 1980 and 1981 was similar to sites $\mathrm{CH} 4$ to $\mathrm{CH} 9$ in 2002 and 2003. ANOSIM analysis indicated that the benthic community changed significantly after 2 decades $(\mathrm{R}=0.743, \mathrm{p}=0.0001)$. SIMPER procedure showed that oligochaetes $(45.21 \%)$, chironomids $(37.66 \%)$ and bivalves $(5.71 \%)$ contributed the largest proportions to the dissimilarity of benthic assemblages between decades. This pattern was confirmed by an overlay of the abundances of these taxa as bubbles on NMDS ordination (Fig. 6). 

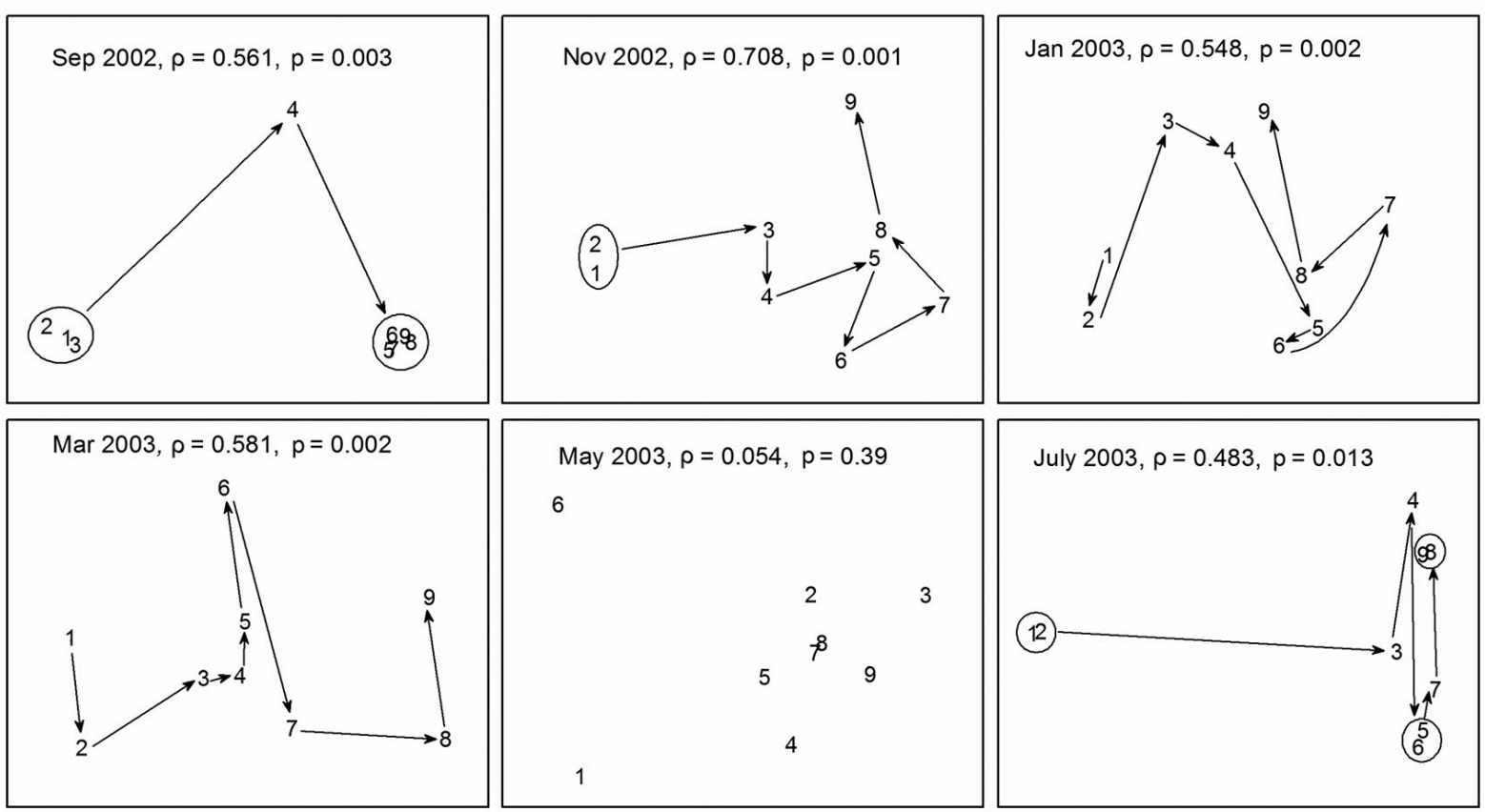

Fig. 4. Spatial trends in species composition of the macrozoobenthic community on each sampling date. Arrows connect spatially adjacent samples. High $\rho$ values indicate that samples close in space were more similar than samples successively more widely separated in space, a pattern called 'seriation' by Clarke et al. (2006).

\section{DISCUSSION}

\section{Community structure and spatiotemporal patterns}

The benthic fauna found at all sampling stations was characterized as being poor in taxonomic composition and diversity, and consisted of pollutiontolerant organisms that are typical of impacted environments, thereby confirming the strong and adverse effect of eutrophication on the taxonomic composition of the zoobenthos. BIO-ENV analysis showed that environmental factors related to nutrient level explained the largest amount of variation in the macrozoobenthos data. In fact, water and sediment chemistry variables related to trophic status have often been cited as important factors influencing the

Table 4. Comparison of the spatial trend on different sampling dates with one another based on Spearman rank correlations $(\rho)$ of their respective similarity matrices. $\rho=1$ indicates $100 \%$ similarity in spatial pattern between different sampling dates; $\rho=0$ indicates no similarity. ${ }^{*} p<0.05 ;{ }^{* *} p<0.01$; ${ }^{* * *} \mathrm{p}<0.005$

\begin{tabular}{|llllll|}
\hline & Sep 2002 & Nov 2002 & Jan 2003 & Mar 2003 & May 2003 \\
\hline Nov 2002 & $0.504^{*}$ & & & & \\
Jan 2003 & $0.537^{* *}$ & $0.759^{* * *}$ & & & \\
Mar 2003 & $0.297^{*}$ & $0.485^{* *}$ & $0.295^{*}$ & & \\
May 2003 & 0.043 & $0.164^{* *}$ & 0.065 & 0.273 & \\
Jul 2003 & $0.625^{* * *}$ & $0.771^{* *}$ & $0.757^{* * *}$ & $0.396^{*}$ & $0.339^{*}$ \\
\hline
\end{tabular}

macrozoobenthos community and standing crop in freshwater ecosystems (Gong \& Xie 2001, Heino 2008, Kilgour et al. 2008, Barquín \& Death 2009, Davies et al. 2010). The taxonomic composition and abundance of bottom fauna depend mainly on food quality and oxygen conditions. In Lake Chaohu, severe cyanobacterial blooms may exert great pressures on benthic fauna through oxygen depletion and production of toxins.

Oxygen depletion (hypoxia), often associated with eutrophication, is a main factor regulating benthic communities on both local and global scales (Diaz 2001). Gray et al. (2002) suggested that the largest effects of eutrophication on benthic fauna often result from hypoxia rather than organic enrichment per se. Other studies indicated that DO levels fluctuate dramatically during severe cyanobacterial blooms (Diaz et al. 2003). Ambient DO concentrations are often supersaturated during the day in these dense accumulations, and the blooms are accompanied by low DO concentrations at night due to the intensive associated respiration. Additionally, the high biomass of cyanobacteria in a bloom is not transferred to higher trophic levels due to its low food quality and inedibility (Gragnani et al. 1999). The decomposition of algal blooms can significantly 

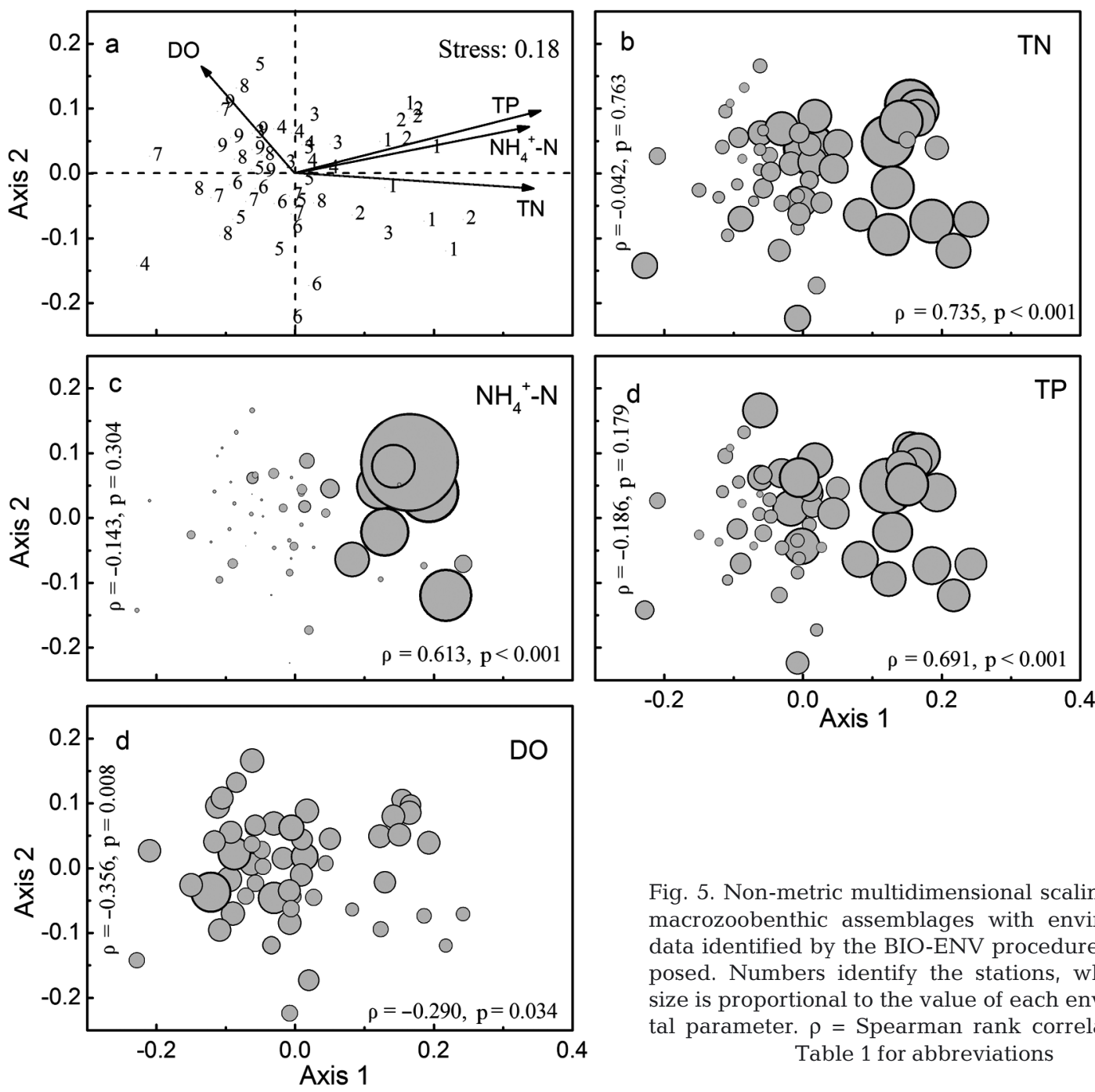

Fig. 5. Non-metric multidimensional scaling plots of macrozoobenthic assemblages with environmental data identified by the BIO-ENV procedure superimposed. Numbers identify the stations, while circle size is proportional to the value of each environmental parameter. $\rho=$ Spearman rank correlation. See Table 1 for abbreviations

Table 5. Changes in nutrient variables (mean $\pm \mathrm{SD}$ ) and major taxonomic groups (mean, range in parentheses) between decades in Lake Chaohu, showing the results of paired $t$-tests (nutrient variables) and Wilcoxon signed-rank tests (macrozoobenthos data). Some published data for cyanobacteria abundance are included to show the development of cyanobacterial bloom between decades. See Table 1 for abbreviations

\begin{tabular}{|c|c|c|c|}
\hline & $1980 \mathrm{~s}$ & $2002-2003$ & $\mathrm{p}$ \\
\hline $\mathrm{TN}\left(\mathrm{mg} \mathrm{l}^{-1}\right)^{\mathrm{a}}$ & $1.85 \pm 0.65$ & $3.56 \pm 1.73$ & 0.022 \\
\hline $\mathrm{TP}\left(\mathrm{mg} \mathrm{l}^{-1}\right)^{\mathrm{a}}$ & $0.115 \pm 0.087$ & $0.102 \pm 0.056$ & 0.582 \\
\hline Chl a $\left(\mu g l^{-1}\right)^{a}$ & $5.01 \pm 4.26$ & $21.78 \pm 11.93$ & 0.008 \\
\hline $\begin{array}{l}\text { Cyanobacterial } \\
\text { abundance }\left(\times 10^{6} \text { cells } 1^{-1}\right)\end{array}$ & $0.25^{\mathrm{b}}$ & $26.24^{\mathrm{c}}$ & \\
\hline Oligochaeta (ind. $\mathrm{l}^{-1}$ ) & $11(0-70)^{\mathrm{d}}$ & $342(100-1067)$ & 0.005 \\
\hline Chironomidae (ind. $\mathrm{l}^{-1}$ ) & $3(0-12)^{d}$ & $404(62-1684)$ & 0.005 \\
\hline Bivalvia (ind. $\mathrm{l}^{-1}$ ) & $61(11-100)^{\mathrm{d}}$ & $13(0-38)$ & 0.006 \\
\hline Gastropoda (ind. $\mathrm{l}^{-1}$ ) & $17(0-77)^{\mathrm{d}}$ & $12(0-29)$ & 0.653 \\
\hline \multicolumn{4}{|c|}{$\begin{array}{l}\text { a Only data from August of } 2 \text { sampling periods were used for comparison; } \\
{ }^{\mathrm{b}} \text { data from Xie (2009); }{ }^{\mathrm{C}} \text { data from Deng et al. (2007); }{ }^{\mathrm{d}} \text { data from Hu \& Yao } \\
(1981)\end{array}$} \\
\hline
\end{tabular}

decrease oxygen content at the bottom layer. Hypoxia will significantly reduce the survivorship of benthic species, especially in the summer months when temperatures are high (Johnson \& McMahon 1998). Corbicula fluminea is among the least hypoxia-tolerant freshwater bivalve molluscs (Matthews \& McMahon 1999). In contrast, oligochaetes and chironomids are known to be tolerant of low oxygen levels (Heinis \& Davids 1993, Verdonschot 1996), while high organic content may favor the production of many species within these 2 families.

Cyanotoxins, mainly microcystins in Lake Chaohu, produced by toxic cyanobacterial blooms are likely to have significant effects on benthic fauna in the 

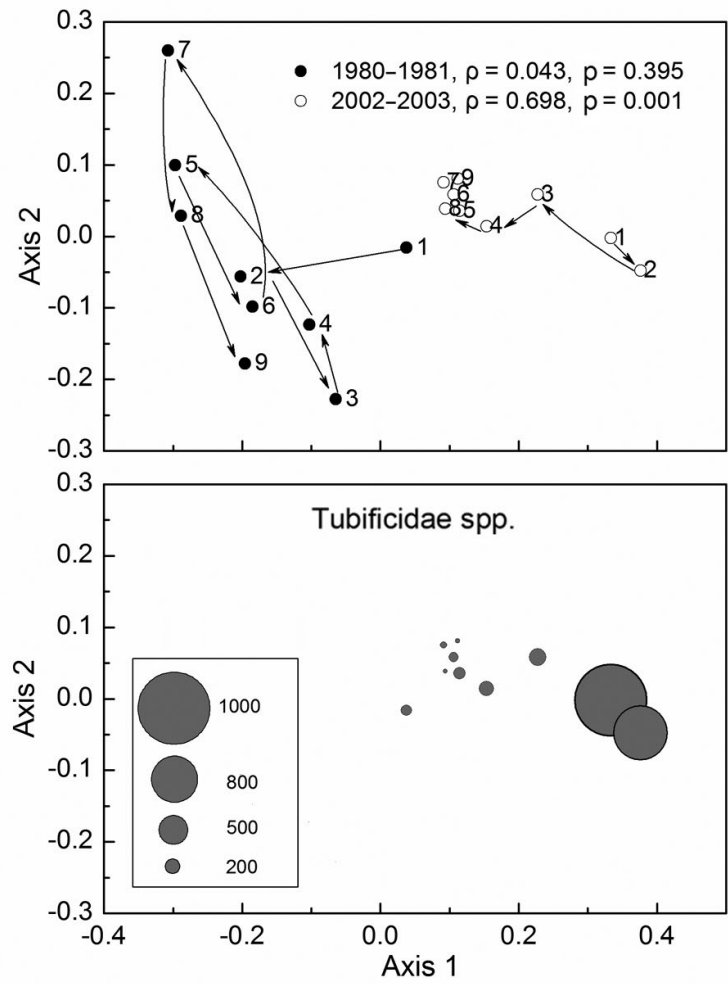
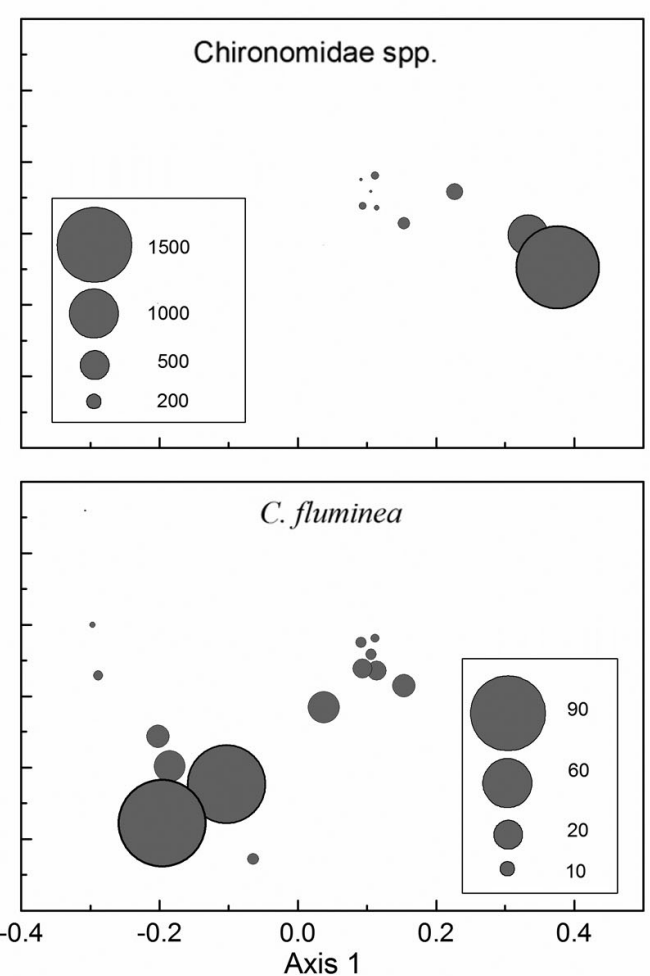

Fig. 6. Non-metric multidimensional scaling plot showing the changes in macrozoobenthic assemblages between 1980-1981 and 2002-2003 in Lake Chaohu, with bubble plots of Chironomidae spp., Tubificidae spp. and Corbicula fluminea superimposed. Bubble size represent mean abundance of macrozoobenthos (ind. $\mathrm{m}^{-2}$ )

long term. Toxic cyanobacteria are often reported to be the cause of mass mortality of aquatic organisms in the field. For example, in a 4 mo study, Oberholster et al. (2009) observed that an increase in microcystins at sites dominated by cyanobacterial scum was accompanied by an increase in the total abundance of the macroinvertebrate families Hirudinae, Chironomidae, and Tubificidae. Gérard et al. (2009) observed that relative abundances of prosobranchs, pulmonates and bivalves were significantly different before and after a cyanobacterial bloom. In fact, several studies indicated that Lake Chaohu was heavily polluted by toxic cyanobacterial blooms and microcystins during warm months. The concentrations of intracellular microcystins reached 2.41 (range 1.0 to 4.6) $\mu \mathrm{g}$ $\mathrm{l}^{-1}$ from May to October in 2002 to 2003 (Yang et al. 2006). Intoxication of Corbicula fluminea $\left(0.53 \mu \mathrm{g} \mathrm{g}^{-1}\right.$ dry weight [DW] in August 2003) and Bellamya aeruginosa (1.69 [0.8 to 4.54 ] $\mathrm{ug} \mathrm{g}^{-1} \mathrm{DW}$ in digestive tracts; 4.14 [1.06 to 7.42$] \mu^{-1} \mathrm{~g}^{-1}$ DW in hepatopancreas) by toxic cyanobacteria was demonstrated by the bioaccumulation of microcystins at high concentrations (Chen et al. 2005, Chen \& Xie 2008). However, it is difficult to distinguish between mortality due to cyanotoxin poisoning and to anoxia caused by decaying cyanobacterial blooms.
In our study, gradual spatial changes in the benthic community from west to east were found at most sampling occasions, but no significant patterns were detected on a temporal scale. In fact, the abundance of dominant taxa showed no clear seasonal changes in our study. Several factors may account for these results. Cyanobacterial blooms make the benthic community composition and diversity susceptible, which may overwhelm other seasonal influences. Kröger et al. (2006) indicated that benthic community composition was approaching recovery $\sim 3$ yr postbloom, and a complete recovery to a pre-disturbance community is likely to take 4 to 5 yr. However, cyanobacterial blooms have occurred every year since the 1980s and lasted from May to November, exerting long-term stress on the benthic community. Furthermore, relatively long life-spans of most macrozoobenthos also lead to their ambiguous temporal pattern.

\section{Decadal changes and implications for conservation}

Our results showed that macrozoobenthic assemblages changed greatly over the long term in Lake Chaohu. Oligochaetes and chironomids increased 


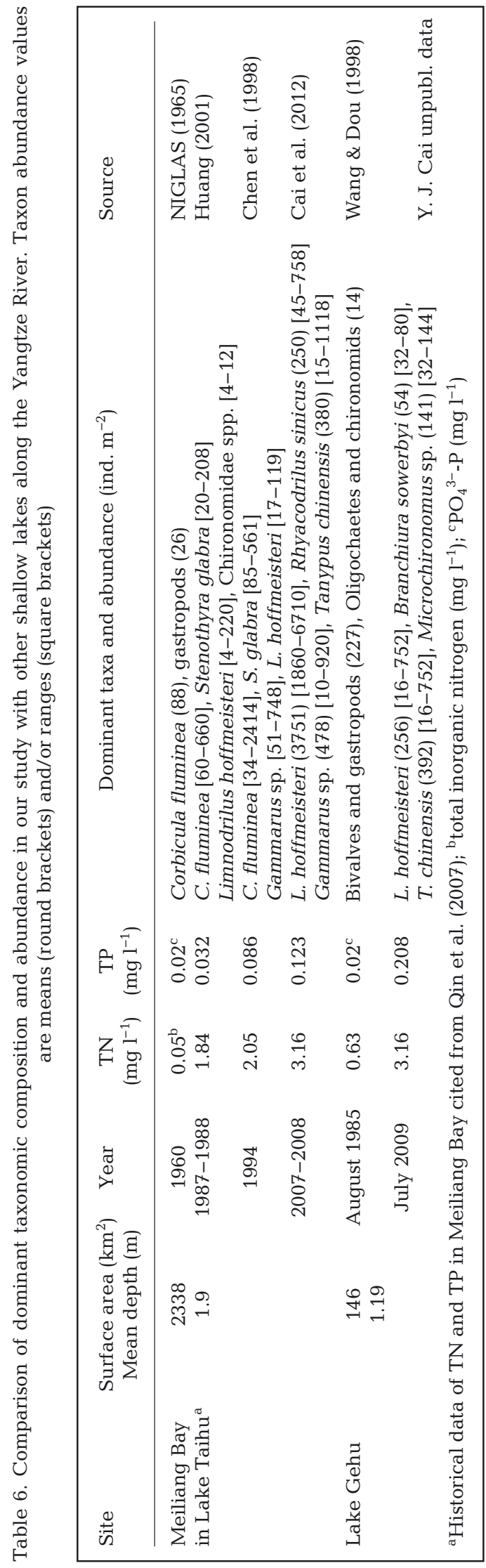

substantially in abundance and exclusively dominated the benthic communities in the present study. Bivalves showed large decreases in abundance and were nearly eliminated in Lake Chaohu. The great changes in macrozoobenthic assemblages showed strong agreement with increased eutrophication and cyanobacterial blooms. The changes are consistent with the model predicted by Pearson \& Rosenberg (1978), which predicts a tendency for dominance of suspension feeders, herbivores and carnivores to shift to deposit feeders in the benthic community as organic input to a habitat increases. The diversity of feeding guilds is progressively simplified due to the decreased number of species. These changes in benthic communities may be a universal phenomenon in shallow lakes along the Yangtze River under severe eutrophication. For instance, in Lake Taihu, the third largest lake in China, several-fold increases in nutrient concentrations have been accompanied by the increasing occurrence and magnitude of cyanobacterial blooms over the past decades (Duan et al. 2009). Benthic communities shifted from domination by Corbicula fluminea and gastropods in Meiliang Bay of Lake Taihu before 1994 to tubificids and chironomids in 2007 and 2008 (Table 6). The abundance of Limnodrilus hoffmeisteri has also increased several-fold. In another example, Lake Gehu also showed similar changes over the long term.

The floodplain of the middle and lower reaches of the Yangtze River contains 108 lakes with a surface area $>10 \mathrm{~km}^{2}$ (Wang \& Dou 1998). However, with the development of extensive agriculture, fishing, farming and urbanization in recent decades, most lakes in this area have undergone eutrophication (Yang et al. 2008). Moreover, human pressure on these lakes will increase over the coming century, exerting great pressures on benthic communities. In fact, about one-third of these lakes were dominated by oligochaetes and chironomids based on an investigation of their water quality and biological resources from 2007 to 2010 (Cai 2011). Simplified benthic communities may have adverse effects on the functioning and services of lake ecosystems, such as energy flow, nutrient cycling, fish production and bird diversity (Gessner et al. 2004). In most cases, different species comprise distinct functional groups that provide ecological integrity, so that any loss of species diversity could be detrimental to continued ecosystem functioning (Covich et al. 2004). In the face of worsening eutrophication, it is time to adopt strategies for managing and rehabilitating degraded ecosystems to preserve freshwater biodiversity. 
Acknowledgements. We thank Donghu Experimental Station of Lake Ecosystems for providing the water quality data. This work was funded by the National Natural Sciences Foundation of China (Grant 31070418 and 31270505) and the Key Program of Nanjing Institute of Geography and Limnology, CAS(NIGLAS2012135002). We thank the 3 anonymous reviewers and the editor for their thoughtful and constructive comments and suggestions.

\section{LITERATURE CITED}

Anderson DM, Glibert PM, Burkholder JM (2002) Harmful algal blooms and eutrophication: nutrient sources, composition, and consequences. Estuar Coasts 25:704-726

Barquín J, Death R (2009) Physical and chemical differences in karst springs of Cantabria, northern Spain: Do invertebrate communities correspond? Aquat Ecol 43:445-455

Cai YJ (2011) Ecological studies of macrozoobenthos in eutrophic shallow lakes of the middle and lower reaches of the Yangtze River. PhD thesis, Nanjing Institute of Geography and Limnology, Chinese Academy of Sciences (in Chinese with English abstract)

Cai YJ, Gong ZJ, Qin BQ (2012) Benthic macroinvertebrate community structure in Lake Taihu, China: effects of trophic status, wind-induced disturbance and habitat complexity. J Gt Lakes Res 38:39-48

Chen J, Xie P (2008) Accumulation of hepatotoxic microcystins in freshwater mussels, aquatic insect larvae and oligochaetes in a large, shallow eutrophic lake (Lake Chaohu) of subtropical China. Fresenius Environ Bull 17: 849-854

> Chen J, Xie P, Guo LG, Zheng L, Ni LY (2005) Tissue distributions and seasonal dynamics of the hepatotoxic microcystins-LR and -RR in a freshwater snail (Bellamya aeruginosa) from a large shallow, eutrophic lake of the subtropical China. Environ Pollut 134:423-430

Chen WM, Guo XM, Reeze B (1998) The study on benthos in Meiliang Bay of Taihu Lake. In: Cai QM (ed) Study on environment and ecology of Lake Taihu, China. China Meteorological Press, Beijing, p 125-133 (in Chinese)

Clarke KR (1993) Non-parametric multivariate analyses of changes in community structure. Austral Ecol 18:117-143

Clarke KR, Warwick RM (2001) Change in marine communities: an approach to statistical analysis and interpretation, 2nd edn. PRIMER-E, Plymouth

- Clarke KR, Somerfield PJ, Airoldi L, Warwick RM (2006) Exploring interactions by second-stage community analyses. J Exp Mar Biol Ecol 338:179-192

Covich A, Austen M, Baerlocher F, Chauvet E and others (2004) The role of biodiversity in the functioning of freshwater and marine benthic ecosystems. Bioscience 54: 767-775

> Davies P, Wright I, Findlay S, Jonasson O, Burgin S (2010) Impact of urban development on aquatic macroinvertebrates in south eastern Australia: degradation of instream habitats and comparison with non-urban streams. Aquat Ecol 44:685-700

> Deng DG, Xie P, Zhou Q, Yang H, Guo LG (2007) Studies on temporal and spatial variations of phytoplankton in Lake Chaohu. J Integr Plant Biol 49:409-418

Diaz RJ (2001) Overview of hypoxia around the world. J Environ Qual 30:275-281

Diaz RJ, Nestlerode J, Diaz ML (2003) A global perspective on the effects of eutrophication and hypoxia on aquatic biota. In: Rupp GL, White MD (eds) Proc 7th Int Symp Fish Physiol, Toxicol Water Quality, Tallinn, Estonia, 12-15 May 2003, EPA 600/R-04/049. U.S. Environmental Protection Agency, Ecosystems Research Division, Athens, GA, p 1-33

Duan H, Ma R, Xu X, Kong F and others (2009) Two-decade reconstruction of algal blooms in China's Lake Taihu. Environ Sci Technol 43:3522-3528

> Fang JY, Wang ZH, Zhao SQ, Li YK and others (2006) Biodiversity changes in the lakes of the Central Yangtze. Front Ecol Environ 4:369-377

> Gérard C, Poullain V, Lance E, Acou A, Brient L, Carpentier A (2009) Influence of toxic cyanobacteria on community structure and microcystin accumulation of freshwater molluscs. Environ Pollut 157:609-617

Gessner MO, Inchausti P, Persson L, Raffaelli DG, Giller PS (2004) Biodiversity effects on ecosystem functioning: insights from aquatic systems. Oikos 104:419-422

Gong ZJ, Xie P (2001) Impact of eutrophication on biodiversity of the macrozoobenthos community in a Chinese shallow lake. J Freshw Ecol 16:171-178

> Gragnani A, Scheffer M, Rinaldi S (1999) Top - down control of cyanobacteria: a theoretical analysis. Am Nat 153:59-72

Gray JS, Wu RS, Or YY (2002) Effects of hypoxia and organic enrichment on the coastal marine environment. Mar Ecol Prog Ser 238:249-279

Hammer $\varnothing$, Harper DAT, Ryan PD (2001) PAST: paleontological statistics software package for education and data analysis. Palaeontol Electronica 4:1-9

$>$ Heinis F, Davids C (1993) Factors governing the spatial and temporal distribution of chironomid larvae in the Maarsseveen lakes with special emphasis on the role of oxygen conditions. Aquat Ecol 27:21-34

Heino J (2008) Patterns of functional biodiversity and function-environment relationships in lake littoral macroinvertebrates. Limnol Oceanogr 53:1446-1455

> Heisler J, Glibert PM, Burkholder JM, Anderson DM and others (2008) Eutrophication and harmful algal blooms: a scientific consensus. Harmful Algae 8:3-13

$\mathrm{Hu} J Y$, Yao WQ (1981) Investigation of macrozoobenthos in Lake Chaohu, China. J Anhui Univ Technol (Nat Sci) 2: 159-173

Huang YP (ed) (2001) The water environment and pollution control of Lake Taihu. Science Press, Beijing, p 72-83 (in Chinese)

> Jackson JK, Füreder L (2006) Long-term studies of freshwater macroinvertebrates: a review of the frequency, duration and ecological significance. Freshw Biol 51:591-603

Jin XC, Tu QY (eds) (1990) The standard methods for observation and analysis of lake eutrophication, 2nd edn. China Environmental Science Press, Beijing (in Chinese)

Johnson PD, McMahon RF (1998) Effects of temperature and chronic hypoxia on survivorship of the zebra mussel (Dreissena polymorpha) and Asian clam (Corbicula fluminea). Can J Fish Aquat Sci 55:1564-1572

Kilgour B, Clarkin C, Morton W, Baldwin R (2008) Influence of nutrients in water and sediments on the spatial distributions of benthos in Lake Simcoe. J Gt Lakes Res 34:365-376

> Kröger K, Gardner JPA, Rowden AA, Wear RG (2006) Long-term effects of a toxic algal bloom on subtidal soft-sediment macroinvertebrate communities in Wellington Harbour, New Zealand. Estuar Coast Shelf Sci 67: 589-604

Liu WZ, Zhang QF, Liu GH (2010) Lake eutrophication asso- 
ciated with geographic location, lake morphology and climate in China. Hydrobiologia 644:289-299

Liu YY, Zhang WZ, Wang YX, Wang EY (1979) Economic fauna of China: freshwater mollusca. Science Press, Beijing (in Chinese)

Matthews MA, McMahon RF (1999) Effects of temperature and temperature acclimation on survival of zebra mussels (Dreissena polymorpha) and Asian clams (Corbicula fluminea) under extreme hypoxia. J Molluscan Stud 65: 317-325

Morse JC, Yang, LF, Tian LX (1994) Aquatic insects of China useful for monitoring water quality. Hohai University Press, Nanjing

NIGLAS (Nanjing Institute of Geography Academia Sinica) (1965) Investigation of Lake Taihu. Science Press, Beijing, p 1-84 (in Chinese)

Oberholster PJ, Botha AM, Ashton PJ (2009) The influence of a toxic cyanobacterial bloom and water hydrology on algal populations and macroinvertebrate abundance in the upper littoral zone of Lake Krugersdrift, South Africa. Ecotoxicology 18:34-46

Pearson TH, Rosenberg R (1978) Macrobenthic succession in relation to organic enrichment and pollution of the marine environment. Oceanogr Mar Biol Annu Rev 16: 229-311

Qin BQ, Xu PZ, Wu QL, Luo LC, Zhang YL (2007) Environmental issues of Lake Taihu, China. Hydrobiologia 581: 3-14

Scheffer M (1998) Ecology of shallow lakes, 1st edn. Kluwer Academic Publishers, Dordrecht

Shang GP, Shang JC (2007) Spatial and temporal variations of eutrophication in western Chaohu Lake, China. Environ Monit Assess 130:99-109

Editorial responsibility: Carolyn Burns,

Dunedin, New Zealand
Smith VH, Joye SB, Howarth RW (2006) Eutrophication of freshwater and marine ecosystems. Limnol Oceanogr 51: 351-355

Tu QY, Gu DX, Yin CQ, Xu ZR, Han JZ (eds) (1990) The Chao Lake: study on eutrophication. Press of University of Science and Technology of China, Hefei (in Chinese)

> Verdonschot PFM (1996) Oligochaetes and eutrophication; an experiment over four years in outdoor mesocosms. Hydrobiologia 334:169-183

Wang HZ (2002) Studies on taxonomy, distribution and ecology of microdrile oligochaetes of China, with descriptions of two new species from the vicinity of the Great Wall Station of China, Antarctica. Higher Education Press, Beijing (in Chinese)

Wang SM, Dou HS (eds) (1998) Lake annals of China. Science Press, Beijing (in Chinese)

Xie P (2009) Reading about the histories of cyanobacteria, eutrophication and geological evolution in Lake Chaohu. Science Press, Beijing (in Chinese)

Xu MQ, Cao H, Xie P, Deng DG, Feng WS, Xu H (2005) The temporal and spatial distribution, composition and abundance of Protozoa in Chaohu Lake, China: relationship with eutrophication. Eur J Protistol 41:183-192

Yang H, Xie P, Xu J, Zheng L, Deng D, Zhou Q, Wu S (2006) Seasonal variation of microcystin concentration in Lake Chaohu, a shallow subtropical lake in the People's Republic of China. Bull Environ Contam Toxicol 77 : 367-374

Yang XD, Anderson NJ, Dong XH, Shen J (2008) Surface sediment diatom assemblages and epilimnetic total phosphorus in large, shallow lakes of the Yangtze floodplain: their relationships and implications for assessing longterm eutrophication. Freshw Biol 53:1273-1290

Submitted: September 14, 2011; Accepted: June 15, 2012 Proofs received from author(s): October 2, 2012 